\title{
Entre apropiaciones, resistencias e intentos de conversión religiosa. Niños y niñas indígenas ante propuestas escolares católicas en Argentina
}

Between appropriations, resistances and attempts of religious conversion. Indigenous children facing Catholic schools projects in Argentina

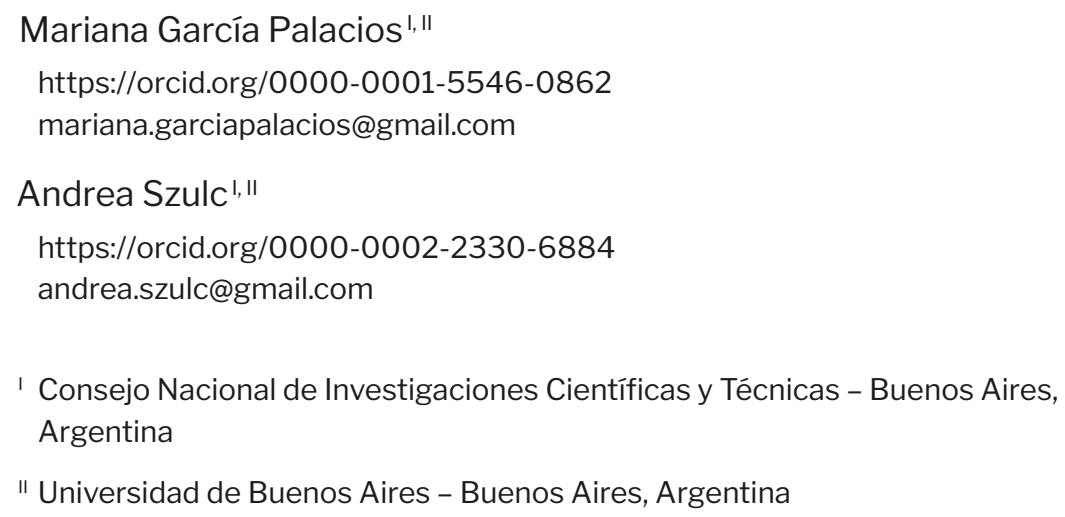




\title{
Resumen
}

Desde el comienzo de los procesos de conquista y colonización de los pueblos indígenas en Argentina, la Iglesia Católica desempeñó un rol crucial, destinando gran parte de sus esfuerzos evangelizadores hacia los niños y niñas de tales pueblos. Esto ha implicado en distintas regiones el desarrollo de una red de escuelas confesionales en las que, de diversas maneras, se ha procurado transmitirles conocimientos y significados religiosos. Nuestro propósito en este artículo es analizar comparativamente las propuestas contemporáneas de distintas congregaciones de la Iglesia Católica hacia los/as niños/as mapuche y tobas/qom, indagando, a la vez, los modos en los que los/as propios/as niños/as recepcionan dichas propuestas. Como tales procesos distan tanto de ser homogéneos como de ser lineales, concluiremos planteando una reflexión antropológica sobre los conceptos de apropiación y agencia infantil.

Palabras clave: infancias; pueblos indígenas; educación católica; agencia.

\begin{abstract}
The Catholic Church has played a key role in the processes of conquest and colonization of indigenous peoples in Argentina. Its efforts were addressed to a great extent to indigenous children. This, in many regions, implied the development of an important net of religious schools where, in different ways, they have tried to transmit to these children catholic contents and meanings. In this paper we set out to analyze comparatively contemporary projects of different catholic congregations towards Mapuche and Toba/Qom children, exploring simultaneously how children themselves receive such proposals. Considering such processes are not homogenous nor lineal, we will conclude putting forward anthropological insights on children's appropriation and agency concepts.
\end{abstract}

Keywords: childhood; indigenous peoples; catholic education; agency. 


\section{Introducción}

Desde los procesos de conquista y colonización de los pueblos indígenas en Argentina, la Iglesia Católica desempeñó un rol crucial, destinando gran parte de sus esfuerzos evangelizadores hacia sus niños/as. Así, en distintas regiones se establecieron escuelas confesionales donde, de diversas maneras, se ha procurado transmitirles conocimientos y significados religiosos. Nuestro propósito en este artículo es analizar comparativamente las propuestas contemporáneas de distintas congregaciones de la Iglesia Católica hacia los/as niños/as mapuche ${ }^{1}$ y tobas/qom, ${ }^{2}$ indagando, a la vez, los modos en los que los/as niños/as recepcionan dichas propuestas.

El artículo se enmarca en la línea de investigaciones antropológicas sobre y con las infancias indígenas en la que trabajamos desde hace tiempo, al igual que reconocidas colegas de Argentina y Brasil (Alvares, 2004; Codonho, 2007; Cohn, 2002; Enriz, 2011; Hecht, 2010; Lopes da Silva; Macedo; Nunes, 2002; Tassinari, 2007, entre otras). Este encuadre implica no sólo estudiar las políticas y prácticas de los/as adultos/as y sus instituciones, sino también relevar y analizar las experiencias y perspectivas de los/as propios/as niños/as. Desde sus comienzos, la antropología se ha interesado por el estudio de la religión, entre otros aspectos socioculturales (Evans-Pritchard, 1991; Malinowski, 1994) y éste continúa siendo un importante campo de indagación en las ciencias sociales (Asad, 1993; Bourdieu, 2006; Carozzi; Ceriani Cernadas, 2007;

1 Actualmente el pueblo mapuche se asienta principalmente en las provincias de La Pampa, Buenos Aires, Neuquén, Río Negro, Chubut y Santa Cruz -en Argentina- y en Arauco, Bio-Bio, Malleco, Cautin, Valdivia, Osorno y Chiloe -en Chile-, con población dispersa en zonas rurales no reconocidas como comunidad y más del 70\% asentada en centros urbanos. En Argentina, la población mapuche ha sido estimada entre 113000 y 300000 personas, dependiendo de la fuente, siendo Neuquén una de las provincias con mayor proporción de población indígena, 7,86\%, según el Censo 2010, que estimó allí 43357 personas mapuche. En Neuquén existen más de cincuenta comunidades mapuche, muchas de las cuales no han logrado la regularización de su personería jurídica ni de sus territorios.

2 Según los datos provenientes del Censo 2010 (INDEC), se estima que en Argentina viven un total de 126967 personas tobas/qom. Aproximadamente el 75\% se encuentra en el noreste del país (provincias del Chaco, Formosa y Santa Fe) y el resto en la región de Buenos Aires, y representan el 13,3\% del total de la población indígena del país. El barrio de la provincia Buenos Aires en el que se encuentra la escuela católica a la que haremos referencia fue construido en 1995 por 32 familias que provenían originariamente de Chaco y Formosa, y que habían migrado principalmente por cuestiones económicas. 
Geertz, 1992; Mallimaci, 1996; Segato, 2007, entre muchos/as otros/as), en particular en cuanto a la relación entre el cristianismo y los pueblos originarios (Guerrero Jiménez, 2005; Montero, 2006; Vilaça; Wright, 2009; Wright, 2008; entre otros/as). No obstante, en el abordaje antropológico de la religión, las experiencias de los/as niños/as han ocupado tradicionalmente un lugar marginal; los estudios sobre religión y aquellos realizados acerca de la niñez y con niños/as aparecían como dos campos escindidos (García Palacios, 2012; Gottlieb, 1998).

Más recientemente, como hemos sistematizado en trabajos previos (García Palacios et al., 2016, 2018), es posible encontrar estudios que relevan etnográficamente la participación de los/as niños/as en prácticas rituales y religiosas, así como las identificaciones religiosas y los conocimientos que construyen a partir de esa participación (Astuti, 2000; Campigotto, 2012; Csordas, 2009; Enriz, 2011; Falcão, 2014; García Palacios, 2006, 2014, 2019; Gottlieb, 1998, 2004; Hall, 1995, 2002; Leitão Souza, 2018; Oliveira, 2005; Palmer; Hardman, 1999; Pires, 2007; Ridgely Bales, 2005; Szulc, 2011a; Toren, 1990, 2003). Por nuestra parte, en investigaciones anteriores, nos hemos dedicado a estudiar con detalle las interpelaciones identitarias dirigidas a los/as niños/as toba/qom, por un lado (García Palacios, 2019) y mapuche, por el otro (Szulc, 2011a), y las identificaciones religiosas que ellos/as construyen a lo largo del tiempo. También a analizar los conocimientos religiosos que construyen al participar de diversas experiencias formativas religiosas (García Palacios, 2012, 2014). Sobre la base de esos trabajos, en esta oportunidad nos centraremos en desplegar un análisis comparativo que, lejos de asumir las realidades empíricas analizadas como totalidades cerradas y coherentes (Dullo, 2019), atenderá a la diversidad y la historicidad de los contextos en los que se sitúa cada referente empírico (Piovani; Krawczyc, 2017), para a partir de allí enriquecer la reflexión antropológica, al asumir la potencialidad y el desafío de la etnografía de producir conocimiento "no prefigurado" (Willis; Trondman, 2000).

En continuidad con los esfuerzos comparativos de trabajos anteriores (Enriz; García Palacios; Hecht, 2017; Leavy; Szulc; Anzelin, 2018), en esta ocasión, nos proponemos contrastar las interpelaciones que diferentes congregaciones de la Iglesia Católica dirigen a niños/as indígenas, mapuche y qom, en diversas regiones de la Argentina, y cómo ellos/as las interpretan, discuten o se las apropian. Intentaremos así iluminar por un lado, las particularidades 
históricas y actuales que marcan la diferencia entre los dos casos estudiados; por otro, la heterogeneidad que registramos dentro de cada uno de ellos, y, por último, las interesantes recurrencias que advertimos en estos procesos vividos por ambos pueblos.

El análisis que aquí desplegamos se basa en las investigaciones etnográficas que venimos desarrollando desde larga data en comunidades mapuche de la provincia del Neuquén (2001-2019) y toba/qom de las provincias de Buenos Aires y Chaco (2006-2019). Nuestra aproximación metodológica incluyó tradicionales técnicas etnográficas como observación participante, entrevistas abiertas e historias de vida con niños/as, jóvenes y adultos/as, junto con recursos complementarios como entrevistas grupales y discusión de casos arquetípicos (en el caso mapuche), y realización de talleres y entrevistas del método clínico-crítico (en el caso toba/qom).

Comenzaremos el escrito situando históricamente el accionar de distintas congregaciones de la Iglesia Católica en relación con las comunidades mapuche de Patagonia, y con las toba/qom de Chaco y Buenos Aires. Incluir un rango histórico en nuestra indagación etnográfica nos permitirá complejizar los abordajes de los procesos contemporáneos y, a su vez, habilitará la posibilidad de cotejar similitudes y contrastes entre las experiencias de estas poblaciones. A continuación, describiremos y analizaremos cómo contemporáneamente -desde las escuelas católicas en que investigamos- se transmiten a los/as niños/as indígenas prácticas y creencias religiosas, configurando procesos que, como veremos, distan tanto de ser homogéneos como de ser lineales. En ese sentido, a partir del trabajo etnográfico hemos podido relevar cómo los/as niños/as interpretan tales contenidos, se los apropian, los impugnan, y/o los transforman, a partir de lo cual, para concluir, plantearemos una reflexión antropológica sobre los conceptos de apropiación y agencia infantil.

\section{De Italia a Argentina: situando históricamente las propuestas católicas y sus escuelas}

Las relaciones entre la Iglesia Católica y los pueblos indígenas en Argentina se remontan mucho tiempo atrás, ya que desde los inicios de la conquista y colonización española la Iglesia fue la encargada de su "conversión” y “civilización" 
(Braunstein; Miller, 1999). En este apartado, describiremos sintéticamente cómo avanzaron diferentes sectores de la Iglesia en las regiones de Patagonia, el Chaco y Buenos Aires, en relación también con el avance estatal y de otras iglesias, para poder así situar sus propuestas contemporáneas hacia los/as niños/as mapuche en Neuquén y qom en Buenos Aires.

El rol desempeñado por la Iglesia Católica ha sido central, tanto en la creación de "reducciones" destinadas a "pacificar" y evangelizar a "los bárbaros", como cuando posteriormente se establecieron pueblos y ciudades. Tempranamente, optaron por la educación de niños/as y su conversión religiosa como estrategia de cristianización de los grupos, convirtiéndolos/as así en vehículos morales y espirituales de las familias (García Palacios, 2012, 2019). Según analiza Priore (1991), respecto del rol de los jesuitas en la colonia en Brasil, la infancia era percibida como un momento oportuno para la catequesis porque se concebía como un periodo ideal para la renuncia a la "cultura autóctona" de los/as niños/as indígenas, ya que ciertas prácticas y valores no se habrían aún sedimentado en ellos/as, convirtiéndolos/as en un catecumenado privilegiado (García Palacios, 2012).

Los jesuitas (Compañía de Jesús) tempranamente instalaron misiones para indígenas en la región del actual noreste argentino, pero fueron expulsados del territorio por la corona española en la segunda mitad del siglo XVIII. Durante el proceso de conformación del Estado Nacional en el siglo XIX continuaron estableciéndose misiones católicas (salesianas, franciscanas, etc.) en distintas zonas del país (Padawer et al., 2017). La promoción de la conversión religiosa se constituyó también en uno de los objetivos del Estado, en alianza con la Iglesia, como quedó plasmado en la Constitución Nacional de 1853 que atribuyó al Congreso Nacional la potestad de suscribir tratados con los indígenas y "promover su conversión al catolicismo", ubicando así a estos pueblos fuera de la Nación (Gordillo, 2006).

Fue la congregación salesiana, arribada a Argentina en 1875, la que se estableció en la región patagónica en $1879 .^{3}$ Los salesianos ingresaron a la Patagonia acompañando al ejército liderado por Roca, tras fallidos intentos propios,

3 Los salesianos son una congregación conformada por sacerdotes y laicos que fundó Juan Bosco como "Pía Sociedad" en Turín, Italia, en 1859. Creada bajo la advocación de San Francisco de Sales, sus miembros se conocen comúnmente como "Salesianos de Don Bosco". 
y luego del fracaso -entre 1670 y 1759 - de las tentativas jesuita y franciscana que provenían de la Araucanía chilena (Briones; Lanata, 2002). Pese a que no acordaban con el grado de violencia de la "conquista del desierto" y a sus temores por las asociaciones que podrían luego hacerse entre la campaña y la congregación, los salesianos justificaron la "conquista" como "acción civilizatoria". El Estado, por su parte, si bien se encontraba en tensas relaciones con la Iglesia, aceptó su presencia como un modo de velar dicha violencia, reeditando la alianza colonial entre la cruz y la espada (Nicoletti, 2008).

En el campo educativo, la oferta salesiana contribuyó con la nacionalización de los recién incorporados territorios (Nicoletti, 2008), pero competía con el sistema de instrucción pública, diferenciándose de éste respecto de la laicidad, la educación conjunta de niños y niñas, y la definición de la población originaria como fuerza de trabajo no calificada. Si bien, como señala Nicoletti (2008), el esfuerzo educativo salesiano fue siempre más allá del ámbito estrictamente escolar, tempranamente se concentró allí, dados los escasos resultados concretos y las dificultades de las misiones volantes y a la posibilidad que las escuelas ofrecían de sobreponerse a la imagen dejada por las campañas militares (Teobaldo, 2000).

En este trabajo, abocaremos nuestro análisis a la propuesta religiosa dirigida a niños/as mapuche por una red de instituciones católicas salesianas de niveles primario, post-primario y secundario ubicadas en la zona de Junín de los Andes, al sur de la provincia del Neuquén. Este centro misionero fue fundado en 1892 debido a su ubicación en un núcleo de reducciones mapuche, a quienes dirigían su accionar. En la actualidad, la impronta salesiana que hizo de esta ciudad un enclave misionero y educativo mantiene vigencia, y asume nuevas formas, por ejemplo como destino de turismo religioso.

En este punto, es importante señalar que, actualmente, en las comunidades mapuche de Neuquén también resulta relevante la presencia de diversas iglesias evangélicas, que desde la década de 1960 tomaron contacto con esta población, procedentes de Chile (Radovich, 1983). Si bien en este artículo no ahondaremos en su accionar, es relevante mencionar su creciente influencia, que entra en "competencia" con las propuestas de la Iglesia Católica y también de las organizaciones con filosofía y liderazgo mapuche (Briones, 1999). Aun así, la relevancia de las instituciones educativas salesianas en Patagonia resulta decisiva, pues han signado la trayectoria de sucesivas generaciones mapuche; 
irradiando a través de diversificadas estrategias el modelo de articulación hasta hoy hegemónico simbolizado por la figura de Ceferino Namuncurá, ${ }^{4}$ muestra y medio aún vigente para la "conversión del indio por el indio", pilar de la metodología salesiana.

En la región del Chaco, el avance de diversas iglesias presenta particularidades que es necesario plantear. Fueron grupos franciscanos quienes al mediar el siglo XIX establecieron misiones en la región (Braunstein; Miller, 1999). Ya en tiempos republicanos avanzados, y tras el "éxito" de las campañas militares sobre las regiones de Pampa y Patagonia, el ejército argentino avanzó sobre la región del Chaco, en lo que se denominó "Conquista del desierto verde" (Lois, 1999). En ambos casos el avance militar fue la estrategia desarrollada por el Estado para ampliar la frontera, tomar posesión de los territorios indígenas, y propiciar el desarrollo capitalista. Entre 1884 y 1912, las sucesivas campañas militares y las expropiaciones de tierras, se complementaron con el creciente avance de los colonos provenientes de la masiva inmigración europea que, según se auguraba, transformaría "el desierto" en un territorio nacional homogéneo y unificado. Estos procesos forzaron a los tobas/qom a sedentarizarse, abandonar en gran medida las prácticas de caza y recolección, e incorporarse al mercado y al trabajo asalariado rural (Ceriani Cernadas, 2008; Gordillo, 2006), y también más adelante provocaron la migración de parte significativa de la población qom a los centros urbanos y sus periferias.

La escolarización de los/as indígenas en establecimientos públicos comenzó a desarrollarse a fines del siglo XIX, en el marco de la creación de colonias y reducciones indígenas (Artieda; Rosso, 2005). Fue entonces que se crearon escuelas públicas para los hijos de los indígenas empleados en los ingenios azucareros (Giordano, 2004). En esos contextos, la educación para indígenas se orientaba principalmente al disciplinamiento de los/as niños/as a fin de poder posteriormente incorporarlos al sistema de trabajo (Artieda; Hecht, 2012), de modo análogo a lo que sucedió con otros sectores sociales en condiciones de desigualdad (Enriz; García Palacios; Hecht, 2017).

4 Ceferino Namuncurá (1886-1905): Nieto de Kalfukura -legendario líder que resistió la ocupación del territorio mapuche-e hijo de Manuel Namuncurá, quien luego de rendirse al Ejército Argentino puso a su hijo bajo la órbita de los salesianos. Fue presentado al Papa León XIII como resultado tangible de la acción salesiana en la Patagonia (Nicoletti, 2008) y murió con sólo 18 años. Fue nombrado venerable por la Iglesia Católica en 1972 y declarado beato en 2007. 
Aunque en líneas generales el avance misional fue similar entre diversas órdenes y congregaciones en distintas regiones de la Argentina, en el Chaco se registran peculiaridades ligadas a la amplia adhesión que lograron entre la población indígena diferentes iglesias protestantes. En este sentido, algunos autores explican los sucesivos fracasos de las misiones católicas entre los qom, por el excesivo paternalismo y autoritarismo que sus reglamentos imponían (Martínez Sarasola, 1992). Frente a esto, el pentecostalismo logró un importante crecimiento, pues a partir de su mayor elasticidad fue apropiado por diversos grupos qom, y dio lugar al llamado pentecostalismo indígena. En el caso toba/qom, estos y otros complejos procesos fueron los que posibilitaron la creación del llamado Evangelio, que en 1958 obtuvo el estatuto legal para la primera Iglesia Indígena Autónoma de la Argentina, llamada Iglesia Evangélica Unida (Wright, 2008). ${ }^{5}$

Con los procesos migratorios y la conformación de barrios tobas en centros urbanos, y sus alrededores, -principalmente en Rosario, La Plata y Buenos Aires- las iglesias del Evangelio se asentaron en otras zonas. Por otro lado, los toba/qom del barrio de Buenos Aires establecieron nuevos contactos con la Iglesia Católica desde la creación del barrio, ya que la escuela católica a la que asistieron o asisten sus niños/as, ubicada frente al barrio, pertenece al mismo obispado que les cedió las tierras.

Específicamente, la Congregación de religiosas encargada de esta escuela fue fundada por una mujer también en Italia, en la década de 1860. Su reglamento estableció que como principal objetivo del Instituto la práctica de la caridad. ${ }^{6}$ Se perfiló así como tarea fundamental la asistencia a "los más necesitados". En la década de 1910, las Hermanas arribaron a la Argentina e instalaron en la ciudad de Buenos Aires un colegio gratuito para niñas para orientarlas en una "mejor dirección" en la vida (García Palacios, 2012). En el actual edificio, recién en 1960 se creó la escuela primaria y, con los años, desapareció el régimen de internado de niñas que había comenzado previamente. Tras la

5 La creación del Evangelio fue analizada como producto del ingreso de iglesias anglicanas en el norte del país, el posterior asentamiento de iglesias pentecostales, los movimientos religiosos liderados por aborígenes y la labor de misioneros menonitas norteamericanos (Ceriani Cernadas, 2008; Ceriani Cernadas; Citro, 2005; Wright, 2008).

6 La caridad es una de las tres virtudes teologales sostenida por la Iglesia Católica (además de la fe y la esperanza) que caracterizarían el obrar cristiano. 
conformación del barrio toba a mediados de la década de 1990, la mayoría de los niños/as comenzó a asistir a esta escuela.

El contrapunto entre los casos del accionar misional católico en Patagonia y Chaco deviene interesante porque se dieron procesos de evangelización diferentes. Por un lado, entre los tobas/qom, luego de los contactos con la Iglesia Católica, fueron ganando influencia diversas iglesias protestantes, que confluyeron en la conformación de un movimiento sociorreligioso indígena que fusiona "elementos tradicionales qom" con otros propios del pentecostalismo. Por otro lado, en el caso de Neuquén la presencia de la congregación salesiana -que se implantó desde el mismo momento de la conquista territorial- ha tenido una extensa incidencia en la población mapuche, a partir de una propuesta de tipo sincrética con la que tradujo al mapuzugun-lengua mapuche- nociones católicas a la vez que avaló ciertas prácticas rituales mapuche. Recién a partir de la década de 1960, las propuestas evangélicas empezaron a disputar la adhesión de esta población desde una propuesta que, hasta ahora, rechaza tanto las tradiciones mapuche como católicas. Son también las propias organizaciones con filosofía y liderazgo mapuche que crecientemente se oponen a ambos tipos de propuestas religiosas. Entre los/as tobas/ qom también es posible encontrar quienes toman distancia de las adscripciones cristianas y reivindican conocimientos ancestrales que las iglesias han estigmatizado.

Analizaremos a continuación las interpelaciones contemporáneas de estos grupos católicos, ambos fundados en Italia dirigidos a los sectores marginales, marcando puntos de continuidad con sus históricos principios y dando cuenta de cómo los/as propios/as niños/as interpretan e inciden sobre sus experiencias en el seno de estas instituciones.

\section{La niñez y la "asistencia a los más necesitados" en colegios e internados}

Las congregaciones católicas cuyas interpelaciones aquí analizamos se han caracterizado, como planteamos, por orientar sus esfuerzos a los/as niños/as indígenas y de otros sectores vulnerados, siguiendo la metodología ya implementada en Italia con niños/as de sectores marginales, como promoción 
implícita o explícita de su asimilación a la "civilización". Tal estrategia se ha apoyado en una particular definición de la infancia, a la vez que en nociones específicas sobre quiénes son los más necesitados, qué es lo que necesitan y cómo asistirlos más eficazmente, cuestiones que aquí analizaremos.

En cuanto a quiénes son y qué necesitan los/as "más necesitados" del Neuquén, el proyecto salesiano estableció tempranamente, a fines del siglo XIX, escuelas con régimen de internado (con alumnos pupilos, semi-pupilos y externos), de acuerdo a su orientación a niños/as de los sectores rurales mapuche y de campesinos pobres procedentes de Chile. Más allá de los motivos prácticos evidentes, existen razones más profundas para esta modalidad, pues, como anticipamos, la infancia era percibida como un periodo ideal para la renuncia a la "cultura autóctona" de los niños/as indígenas y su conversión al catolicismo. Así, se consideraba que la separación de los/as niños/as de su entorno familiar y cultural facilitaría la conversión, "cortando este circuito de transmisión" (Delrio, 2001, p. 135). La definición de qué es lo que los indígenas necesitan incluye no sólo la evangelización sino cierto ideal civilizatorio que promovió fuertemente la sedentarización, el trabajo agrícola y la adecuación a pautas de vida "civilizada" (Nicoletti, 2008).

En el caso de la escuela católica de provincia de Buenos Aires, cuyo pilar desde su constitución ha sido la caridad orientada "hacia los más necesitados", no se preveía específicamente el trabajo con población indígena en sus comienzos. Los/as niños/as tobas fueron incluidos/as a partir de su migración a mediados de la década de 1990, cuando se evidenció, en articulación con el principio de caridad, una adecuación al discurso de la "tolerancia a la diversidad", extendido en la agenda pública en ese momento, que, como veremos más adelante, también fue impregnando a las escuelas salesianas de Neuquén. Así, como explicó un docente catequista:

Vos firmás el contrato e ingresás al colegio. En el contrato está estipulado [que los/as niños/as deben tomar la Primera Comunión]. [En el caso del barrio qom] los padres optaron por otra religión, pero se les da la oportunidad de que sigan porque tienen la escuela enfrente [...] Eso un poco también tiene que ver con la caridad de la escuela y de la Iglesia, ¿viste?, no excluir. No excluir, con ellos se hace eso, tienen ese ¿cómo es que se dice?... Ese privilegio, por decirlo de alguna manera, con ellos, pero nada más. 
La inclusión de los/as niños/as en el establecimiento se concibe como un acto caritativo de parte de la escuela. Se reactualiza así la vieja categoría teologal de la caridad que, a partir de la década de 1950, había sido recreada para reemplazar a la categoría de beneficencia, ya caída en desuso (Zapata, 2005). En este sentido, el accionar de la Iglesia Católica ha sido insoslayable en el disputado campo de la "asistencia" y la "cuestión social" en el país (García Palacios, 2018), presentándose como la contracara, en materia de asistencia, promoción o política social de lo que el Estado hacía o dejaba de hacer (Zapata, 2005). Esto adquirió particular relevancia en el momento de conformación del barrio toba/ qom, a mediados de la década de 1990, en un contexto social profundamente marcado por la "crisis del estado de bienestar", que implicó un crecimiento de la marginalidad y una fragmentación heredada del período dictatorial, en cuyo marco la intervención de la Iglesia resultaba crucial (Santillán, 2009). Según la asistente social de la escuela:

Bueno, se hizo el contacto con la curia, les regalaron los terrenos [...] la gente que vivía acá en los barrios se empezó a sentir mal, dicen ¿cómo viene gente de afuera, nosotros viviendo acá? [...] gente muy pobre había [...] Dijeron que eran evangélicos. Entonces la escuela les permitió igual venir.

La caridad practicada por esta congregación hacia "los más necesitados" trasciende la inclusión de los/as niños/as del barrio en la escuela. Desde la congregación se afirma haber distribuido y donado diversos bienes y recursos que van desde las tierras hasta albergue en la escuela para los/as primeros/as que llegaron al barrio (mientras construían las casas), donaciones de ropa, ayuda con trámites de documentaciones, y con la solicitud y distribución de planes y subsidios del Estado. Pero mientras que las tierras, desde la escuela, aparecen mayoritariamente como un "don", para los/as habitantes del barrio representan la confluencia de diversas experiencias y acciones colectivas organizadas para demandar el cumplimiento de un derecho (Hecht, 2010).

Así como los salesianos en Neuquén tempranamente apelaron a la educación de los/as niños/as mapuche "para llegar a sus padres", la idea de que se facilita la transmisión religiosa en la infancia también puede rastrearse en el colegio de Buenos Aires. Veamos, por ejemplo, un fragmento de la Revista de la congregación: 
La acción de una maestra de Jardín de Infantes, es, en cierto sentido, de mucha más responsabilidad [...] [porque] tiene la posibilidad de una comunicación directa que en una criatura totalmente disponible como es el niño, imprime una huella que difícilmente se podrá borrar [...]

Esta visión de la niñez concuerda con la construcción hegemónica dentro de la Iglesia Católica ligada a la inocencia, la natural bondad, la pureza, la maleabilidad, y la incapacidad para mentir (García Palacios, 2006, 2012; Szulc, 1999). Diversos autores (Ariès, 1987; Gélis, 1990) han mostrado cómo los/as más jóvenes fueron el objetivo privilegiado para la asimilación de la ortodoxia por parte de los reformadores católicos, bajo la idea de una necesaria iniciación temprana en el aprendizaje de la fe, la moral y las buenas costumbres (Varela; Álvarez Uría, 1991).

Si los/as niños/as son maleables entonces quien actúa es quien los/as moldea. Tal noción de infancia resulta ajena para diversas comunidades indígenas, en las que a los/as niños/as, además de formarlos/as, se les reconoce un interesante margen de autonomía (García Palacios, 2012; Szulc, 2011b; Tassinari, 2007). Esto puede observarse, por ejemplo, respecto al ingreso y permanencia en los internados en Neuquén, decisión en la que hemos registrado cómo los/as niños/as mapuche logran realizar ciertas maniobras. Mientras algunos/as persuaden a sus familiares para poder trasladarse allí; otros/as se "escapan" de estas escuelas valiéndose de alguna salida por vacaciones. Así, hemos relevado numerosos testimonios sobre cómo para muchos/as niños/as, resulta difícil de sobrellevar el estar internados/as; abundan los relatos acerca de compañeros/as que lloran por las noches y del propio padecimiento, como manifestó con lágrimas en los ojos una niña de 11 años: "extrañaba mucho a mi mamá". En esto también inciden situaciones de discriminación que tornan a estos colegios en un ámbito hostil. En este sentido, debemos considerar los casos de quienes se "escapan", como ocurrió por ejemplo con una niña de 13 años, quien en lugar de retornar a la comunidad, permaneció oculta en casa de una hermana en la ciudad alegando encontrarse enferma, hasta que unas semanas más tarde su madre la encontró allí al ir a hacer compras. Habiendo prácticamente perdido la condición de alumna regular por la acumulación de inasistencias, la niña logró ya no retornar al internado. Al regresar junto con su madre a la comunidad, consumada ya la "deserción", obtuvo el aval de 
su padre, quien le dijo "Che, vos sos igual que los chivitos, los dejas un ratito y ya se vienen".

Los internados religiosos salesianos pueden clasificarse como un tipo de institución total que, a diferencia de otras, ofrece "al interno la oportunidad de vivir de acuerdo con un modelo de conducta que el personal superior patrocina y que es, según sostienen su defensores, el que más conviene a los intereses de las mismas personas a quienes se aplica" (Goffman, 1998, p. 73). De este modo, no operan de modo meramente represivo sino que promueven un ideal, forjado a fines del siglo XIX alrededor de la formación de "un hombre educado en el marco de la moderación, el amor a Dios, la moral más pura, la sujeción de los hijos a los padres y la obediencia a la autoridad" (Teobaldo, 2000, p. 138). Es así que la reclusión se revela como productiva, no meramente represiva (Foucault, 1989). Por una parte, impone una discontinuidad con su medio habitual, y es padecida en sí misma: “Como yo nací así, libre, no me simpatizó estar encerrada todo el día" (niña mapuche, 13 años). Por otra parte, a partir de tal ruptura, el encierro se torna una vía privilegiada para la transmisión de determinadas interpelaciones identitarias: "Como estás ahí metida, en algo tenés que distraerte. Te pasan películas y te vas creyendo que eso es verdad, cómo Jesús vino a la tierra y todo eso" (joven mapuche). Sin embargo, la conceptualización como "instituciones totales" no debe cegarnos frente a los indicios de fisuras provocadas por los/as niños/as, algunas de las cuales hemos mencionado.

En el caso de la escuela de Buenos Aires, el régimen de internado de niñas que había comenzado en la década de 1940 desapareció tras ser fundada la escuela primaria en 1960. Cuando comenzaron a ingresar los/as niños/as del barrio qom, ya se trataba de una institución de jornada simple. Estos/as niños/as también negocian y tienen cierto margen de decisión acerca de su concurrencia diaria a la escuela, como relevamos frecuentemente en el trabajo de campo. Desde la institución esto suele verse como una falta de autoridad de los padres: "los padres no tienen autoridad sobre los niños. Hay unas nenas que viven literalmente frente a la escuela, y les iba bien, ¿eh? Pero de 140 días de clase, vinieron 80. Se quedan libres..." (Hermana de la orden, vicedirectora).

Estas prácticas dan cuenta de la capacidad de agencia de los/as niños/as, no sólo en sus relaciones con el personal de la institución sino sobre todo dentro de sus familias; e invitan a "resistir los efectos del análisis, fundamental pero a menudo exclusivo y obsesivo, que se ocupa de describir las instituciones 
y los mecanismos de la represión [...] [que] tiene por inconveniente no ver las prácticas que le resultan heterogéneas y que reprime o cree reprimir" (Certau, 1998, p. 47-48, énfasis del autor). Como planteamos en otros textos, los/as niños/as mapuche y toba/qom desde muy pequeños/as son incentivados por sus familias y comunidades a manejarse con un amplio margen de autonomía (García Palacios, 2014; Szulc, 2011b, 2019). Hemos registrado cómo los/as niños/as que alcanzan ya la edad escolar intervienen en la decisión de a qué escuela concurrir, si prometer lealtad a la bandera argentina o no, o simplemente si asistir o no a la escuela en el día a día, en cuáles actividades y de qué iglesias quieren participar, y sus decisiones suelen ser respetadas por las familias. En este sentido, como desarrollaremos más adelante, su capacidad de acción es notable, pero no debe llevarnos a considerarlos/as como plenamente autónomos/as, omitiendo las dispares relaciones de poder en las que sus vidas transcurren. Los diferentes contextos son clave para entender cómo la agencia social de los/as niños/as se despliega, cómo es limitada o, en algunos casos -como los que aquí trabajamos- incentivada por las familias y comunidades indígenas de acuerdo con las concepciones nativas acerca de la niñez, la persona y el cuidado.

\section{La "educación integral"}

En Argentina, al igual que en otros contextos, la Iglesia Católica se propuso desarrollar, sobre todo en los internados y colegios, una educación llamada "integral", que no se limitaría a una formación científica de la currícula básica, sino que también incorporaría las dimensiones de la moral y el espíritu (García Palacios, 2012). Generalmente, además, incluía una "capacitación laboral" (Szulc, 2011a).

En este sentido, para los dos casos estudiados aquí encontramos propuestas escolares en las que, además de la instrucción básica y obligatoria, se incluye enseñanza religiosa. Esto es así porque las escuelas católicas forman parte de la evangelización promovida por la Iglesia.

En concordancia, la congregación salesiana se ha contrapuesto históricamente al sistema de instrucción pública, al que concibe como espacio signado por un "liberalismo ateo" (Teobaldo, 2000), por lo que en los internados 
neuquinos la formación religiosa ha sido un objetivo central, instrumentado mediante diversas modalidades.

Por un lado, se imparte en espacios formativos explícitamente dedicados a ese fin, las clases de catequesis, en las que se utilizan procedimientos expositivos que apuntan a una incorporación de los contenidos a nivel intelectual: "nos enseñaba así las cosas de dios, escribíamos, leíamos el nuevo testamento" (niña, 11 años); "te enseñaban el Padre Nuestro, el Ave María, el Credo, los diez mandamientos, todo para que estemos bien informados" (joven mapuche). Resulta necesario resaltar que no se trata de cualquier "información", sino de la requerida para incorporarse al ritual de la primera comunión y la confirmación.

Por otro lado, la interpelación en términos católicos impregna fuertemente la rutina de estos establecimientos, a través de la bendición de la mesa antes de cada comida, o del despliegue de simbología católica sincrética en los lugares destinados a la enseñanza, el trabajo y el descanso. También se requiere de los/as alumnos/as una activa participación en el ceremonial católico, lo cual promueve un compromiso con la comunidad cristiana a nivel vivencial, apelando para ello a lo musical, lo cual es señalado reiteradamente por los/as niños/as como uno de los aspectos que suscitan su adhesión.

Además, quienes asisten a estas instituciones son litúrgicamente incorporados/as a la feligresía católica puesto que, a diferencia de otras comunidades cristianas que pueden reservar los espacios sagrados para los/as adultos/as, en la Iglesia Católica los/as niños/as juegan un rol especial (García Palacios, 2019; Orsi, 2005). Por lo mismo, se espera que realicen ceremonias específicas como la primera comunión y la confirmación, las cuales -como plantea García Palacios (2006) retomando la conceptualización de Bourdieu (1985)- constituyen ritos de institución, mediante los cuales se opera una separación que institucionaliza una diferencia fundamental entre aquellos abarcados por el rito y aquellos que nunca lo serán. La inclusión operada por estos rituales se presenta como irreversible, como puede observarse por ejemplo en las tarjetas que algunos niños/as conservan como souvenir, con leyendas como la siguiente: "Nunca Jesús ha de consentir, que quien hoy lo abraza, se aparte de ti”. Sin embargo, etnográficamente hemos relevado que esta consigna es frecuentemente transgredida por adultos/as y niños/as mapuche que, al adherir posteriormente a alguna iglesia evangélica o bien a alguna organización con filosofía y liderazgo mapuche, se desafilian de facto. 
Por su parte, el "ideario" de la escuela de provincia de Buenos Aires contempla entre otros objetivos, el formar cristianos/as comprometidos/as, realizar la síntesis entre "Fe-cultura y Vida", y favorecer la integración de la comunidad educativa con la labor pastoral, parroquial y diocesana, promoviendo la comunión eclesial. Así, además de la simbología católica también desplegada en este espacio, los/as estudiantes participan de ciertas actividades ritualizadas en las que se vinculan con la religión católica. En principio, dos veces por semana tienen clases de catequesis que deben aprobar. No obstante, desde la escuela se concibe que en los distintos espacios se transmite "sin obligar": "Nosotros los integramos, son de otra religión, el colegio es católico; sólo les pedimos que participen de oyentes [...] No necesitan participar rezando, no se los obliga, pero sí de oyentes porque luego tienen la libertad cuando sean más grandes..." (vicedirectora); "participan de la catequesis e incluso se les pide que tengan el libro; no se les obliga a recibir el sacramento [de la eucaristía], pero sí a participar de la clase ..." (catequista).

Es importante notar que aquí la "no obligación" sólo cobra sentido frente a la obligación que los/as alumnos/as no indígenas tienen de cumplir con los sacramentos y rituales estipulados (García Palacios, 2018). De todos modos, no deja de implicar cierta "imposición", en el sentido de que la "religión oficial" no se impone exclusivamente gracias a coerciones y enseñanzas directas, sino a disposiciones que en la práctica cotidiana se inculcan de modos más imperceptibles (Bourdieu, 1985). En una entrevista, una niña del barrio de 12 años que asiste a la escuela, sostuvo que lo que aprende en el barrio y en la escuela "es distinto [...] allá es catequesis, y acá como el Evangelio es otro. Ahí rezan, se arrodillan, hacen la señal de la cruz y acá danzan, oran". Ella dice ser evangelio y que en la escuela "la seño Marta siempre nos lee las palabras de Dios a la entrada y cuando nos vamos. Nos hacemos la señal de la cruz o sino un 'Padre nuestro'”. Luego asegura: "No es obligatorio [...] pero hay que hacerlo igual, pero papá me deja. Tengo que hacer todo lo que ellos [los de la escuela] dicen" (niña, 12 años).

A su vez, en tanto aquí la formación católica forma parte de la currícula de la escuela, se entrelaza con ciertos saberes típicamente escolares: "Vos como docente incluís la religión en las distintas áreas. Dando la clase, les hablo de Jesús, de los valores... para mí es importante darles a conocer mi religión. Mi fe está por encima de todo. Transmitir, pero no obligar..." (vicedirectora). Y: "Los alumnos todo lo terminan relacionando con la religión [en referencia a una 
actividad por el aniversario de la muerte de San Martín en la que se postulaban sus valores cristianos]. Tienen desde [nivel] inicial y a esta altura ya tienen todo incorporado..." (maestra de $3^{\circ}$ grado).

Volviendo al caso neuquino, también allí relevamos que las diversas instancias de formación religiosa son formal o informalmente obligatorias para los/as alumnos/as. Por ejemplo, la exigencia -para quienes residen allí como pupilos/as- de concurrir a la misa dominical se instrumenta mediante el argumento práctico de que "no nos pueden dejar solas" y a través de la asignación asientos fijos en el recinto. Así, a modo de panóptico, se somete a los internos a "un campo de visibilidad" (Foucault, 1989, p. 208) que, al dejar en evidencia fácilmente la ausencia de alguno/a, transmite eficazmente la obligatoriedad de hecho de la actividad: "los domingos tenía que ir a misa. Había que ir, allá tenemos ya los lugares y había una hermana responsable de las chicas" (niña, 11 años).

Tanto entre la población qom como entre la mapuche, el trabajo etnográfico nos permitió relevar valoraciones heterogéneas respecto de esta formación religiosa. En el primer caso, algunas familias presentan sus diferencias como irreconciliables, en términos dicotómicos ("su religión" y "la nuestra", "su cultura" y "nuestra cultura") y otras no lo viven como una distancia que imposibilite el intercambio. Así, mientras que algunas familias "sacan" a los/as niños/as de la escuela por considerar insalvables estas diferencias, otras avalan su participación en las distintas actividades religiosas, incluidos el bautismo y la primera comunión en el caso de un niño y una niña que mostraron interés, como veremos más adelante. En el caso de los/as niños/as mapuche, algunas familias aprecian justamente la formación religiosa, apropiándose de la interpelación en términos católicos, en tanto otras consideran que se trata de un área sobredimensionada -"en la escuela del Malleo es mucha la presión con el tema de la religión"- o, más aún, de una imposición orientada a la subordinación de la población mapuche: "quieren someternos con una religión que no nos pertenece" (joven, 18 años). Para este caso -y a diferencia de la escuela de Buenos Aires- es importante tener en cuenta que como parte de la "educación integral" del proyecto civilizador de la congregación salesiana (Nicoletti, 2008), sus escuelas han incluido históricamente la capacitación en oficios, lo cual es una de las razones por las que numerosas familias mapuche continúan eligiendo estas escuelas para sus hijos/as, pues ofrecen la posibilidad de una 
inserción económica alternativa al trabajo no calificado asalariado o a la mera desocupación.

De cara a la discusión que aquí nos proponemos acerca de los modos en que los/as niños/as indígenas recepcionan la educación religiosa, si se apropian de lo que se les enseña y cómo lo hacen, en el caso de Neuquén el trabajo etnográfico ha revelado diversas formas en las cuales ellos/as hacen usos diversos de los espacios y tiempos destinados a tal fin, de acuerdo con sus intereses. Por una parte, hemos registrado el caso de una niña mapuche que, al promediar en el internado el período de preparación para tomar la primera comunión, decidió aprovechar la oportunidad que se le presentaba de tomarla en su comunidad rural de origen: "para hacer la comunión en Junín tenés que prepararte dos años, para recién poder tomarla. Entonces para mí fue más rápido poder tomarla acá. Me preparé en Junín y la vine a tomar acá, más rápido. Si no, me quedaba un año más todavía". Es decir que, habiéndose apropiado del mandato de tomar la primera comunión, empleó los recursos a su alcance para acelerar su preparación. Por otra parte, hemos registrado la sugerente reconversión de estas instancias para otros fines que hacen algunos/as adolescentes, que no sólo evaden la reclusión que supone el internado, sino que lo hacen utilizando como recurso los canales institucionales. Así, en ocasiones, tomaban y refuncionalizaban el tiempo y los medios destinados a su formación católica para irse "a joder"7 y gozar del esparcimiento mundano, esfera de la cual la congregación explícitamente procura mantenerlos/as alejados/as. También, resulta interesante el caso de una niña mapuche de 11 años, que al entrevistarla cursaba su escolaridad en un internado católico cuando, durante una visita a su casa durante las vacaciones, encontró que su familia extensa se había tornado evangélica, y le insistían en que debía "elegir un camino, no podía seguir en dos iglesias". Basándose en sus experiencias en ambas prácticas ella propuso, en cambio, una posible síntesis entre ellas, interpretando sus diferencias como sólo una cuestión de forma, no de contenido: "Para mí es todo lo mismo, porque en cambio acá oramos, pero allá oran también, pero no oran así la misma forma que acá hacemos. Allá veo que oran pero así parados nomás y acá todos arrodillados".

7 Divertirse, entretenerse. 
Para el caso del barrio toba/qom, también registramos diversas formas de recepcionar las propuestas de la escuela. Existen, por un lado, ciertas estrategias más o menos sutiles de los/as niños/as y jóvenes, para sustraerse de las interpelaciones católicas. Por ejemplo, una alumna de la escuela católica de 15 años de edad relató que le confundían las "dos religiones, ir a una escuela y creer en otra cosa." Al entrevistarla también relató cómo enfrentaba esa dificultad:

Y no sé, cuando la profesora explicaba algo de un santo, yo no escuchaba. O me levantaba, así me sacaban afuera. Yo no escuchaba [...] O si no, decía: 'profe, ¿podemos hablar de otra cosa?’ y ‘de qué querés hablar?’ y le cambiaba el tema a la profesora así la profesora no hablaba de eso [...].

Por un lado, lo que se pone en evidencia son algunos de los modos en que los/as niños/as hacen frente a las situaciones en las que se encuentran con contenidos de los que finalmente no se apropian. Así, los niños/as del barrio toba llevan a cabo diversas estrategias, como evidencia este otro ejemplo:

Por ahí me burlaba con mis compañeros, pero siempre delante de ellos [...] mantenía ese respeto, ¿viste? [...] Solamente cuando [...] me decían Jesús o Dios les creía y pensaba está bien, pero ya cuando me hablan de las vírgenes, de los santos, yo no.... Entraba por acá [señala un oído] y salía por el otro lado (joven, 17 años).

Por otro lado, también registramos cómo dos hermanos/as, una niña y un niño, decidieron tomar la primera comunión junto con sus compañeros/as de la escuela, decisión que su familia apoyó aun cuando ellos/as mismos/as forman parte de una iglesia del Evangelio. Incluso en estos casos es posible hallar un rol activo por parte por parte de los/as niños/as, que hacen uso de lo aprendido de acuerdo con sus propios posicionamientos, como podemos observar en el siguiente fragmento de entrevista con un niño de 13 años:

Mariana: ¿Te parece parecido lo que enseñan ahí de catequesis y eso y lo que enseñan acá en el barrio? ¿O es distinto, qué te parece?

Javier: Para mí es distinto porque... ahí ellos como que tienen otros santos... como San Francisco, todo eso. Sí, a mí a veces no me gusta... porque te dan una tarjetita 
[una estampita] y vos tenés que rezar y eso no me gusta porque como que ya estás adorando a ese santo [...] ahí ya son muchas estatuas.

Mariana: Y vos, cuando tomaste la comunión, ¿no sentiste como que formabas parte de "ellos"? Porque decís "ellos tienen"...

Javier: A la vez sí...

Mariana: ¿A la vez sí?

Javier: Yo, a veces, quería hacer acá [en el barrio]... pero no me animé [...] Y no fui más hasta ahora. Porque yo ya estaba bautizado allá [en la católica] y otro bautismo no... porque no... No sentía hacer dos veces eso. Porque como recibí una vez y vas a recibir otra vez. Y... me quedé ahí nomás...

Los materiales etnográficos presentados para ambos contextos empíricos evidencian la relevancia de atender a qué hacen los/as niños/as con los contenidos que se les procura transmitir, para lo cual, como desarrollaremos más adelante, resulta sugerente el concepto de apropiación, -que tiene antecedentes en psicología (Rogoff, 1997; Wertsch, 1998)-y que fue incorporado al campo de la antropología y educación como contrapeso al concepto de socialización (Rockwell, 1997, 2011), para dar cuenta de los modos en los cuales los/as niños/as se involucran activamente en el conjunto de relaciones y prácticas cotidianas (escolares, familiares u otras) y que condicionan el sentido de sus apropiaciones. Al mismo tiempo, permiten advertir que "la capacidad de agencia puede ser encontrada no sólo en actos de resistencia a las normas sino también en las múltiples formas en que esas normas son incorporadas" (Mahmood, 2019, p. 131, nuestra traducción).

\section{Interpelaciones identitarias: la "cultura indígena" y los niños/as como "católicos" o "no católicos"}

En este último apartado nos detendremos a analizar si y cómo estas propuestas católicas incorporan la pertenencia indígena en sus interpelaciones hacia los/as niños/as mapuche y qom, qué sentidos promueven sobre ella y si la articulan en la construcción de un "nosotros" católico.

En el caso de la provincia del Neuquén, la definición identitaria que promueve la Iglesia Católica articula explícitamente la pertenencia mapuche 
a través de una propuesta sincrética. ${ }^{8}$ Principalmente, lo hace recurriendo a la imagen de Ceferino Namuncurá, como ya planteamos, en tanto arquetipo de articulación coherente y a-conflictiva. Así, en tanto mapuche, la imagen de Ceferino ha operado históricamente como medio para la creación de un "nosotros" inclusivo, al cual toda persona mapuche podría adscribir sin renegar de tal pertenencia, pero poniéndola al servicio de los ideales cristianos. Esta interpelación en la que se combinan las pertenencias mapuche y católica se continúa transmitiendo actualmente a los/as niños/as mapuche a través de la profusa utilización de nociones cristianas inculturadas mediante su traducción al mapuzugun y de reinterpretaciones de prácticas rituales mapuche en clave católica. A estas traducciones y apropiaciones de la religiosidad mapuche por parte de la Iglesia Católica se oponen, sin embargo, diversas organizaciones con filosofía y liderazgo mapuche. ${ }^{9}$

De este modo, la congregación salesiana se presenta públicamente en la Patagonia no sólo como tolerante de las tradiciones mapuche sino, más aún, como artífice de su vigencia. Por ejemplo, el instituto Ceferino Namuncurá se promociona como "una escuela que mantiene viva la Cultura Mapuche" (Una escuela..., 2007). En el conjunto de escuelas religiosas aquí abordadas se dictan clases de idioma y cultura mapuche -incluso muchos años antes de que esto se incorporara en las escuelas públicas ubicadas en las comunidades rurales (Szulc, 2011b)- en las que lo mapuche pasa por el tamiz de la "lógica escolar" y es crecientemente incorporado a la cotidianeidad institucional. ${ }^{10}$

8 Sin pretender aquí zanjar la discusión en torno al debatido concepto de sincretismo, haremos uso de él concibiéndolo no como una espontánea "fusión" de creencias y prácticas religiosas procedentes de tradiciones previamente puras, sino como un proceso conflictivo que, imbricado en las relaciones de poder y desigualdad, dista mucho de ser inocente, coherente o acabado.

9 En cuanto a la traducción al mapuzugun de la noción monoteísta de "Dios" como "ngenechen", sostienen que constituye una noción ajena a la cosmovisión mapuche, coincidiendo con investigaciones históricas que señalan que se trata de una idea inculturada por misioneros jesuitas en tiempos coloniales, que retomaron posteriormente los salesianos (Nicoletti, 2008). Respecto de lo segundo -al igual que al revitalizar el katan kawiñ y lakutún-las organizaciones han desarrollado un amplio esfuerzo para desestimar la denominación de "rogativa" y la "contaminación" con simbología cristiana, interpelando en cambio a los niños/as desde una concepción contestataria de lo que supone ser mapuche (Szulc, 2018).

10 En una de estas escuelas, por ejemplo, en el año 2018 permitieron que algunos/as niños/as mapuche prometieran lealtad a la bandera mapuche, en lugar de a la bandera argentina. 
En este punto encontramos grandes diferencias con el caso toba/qom. Si bien existen proyectos escolares católicos en los que se promueven, aun conflictivamente, contenidos culturales qom -por mencionar uno: una escuela franciscana intercultural en Chaco-, en Buenos Aires, como anticipamos, es recién con el arribo de las familias al barrio que la congregación de religiosas se vincula con una comunidad indígena. La incorporación en la escuela de los/as niños/as del barrio supuso en algunos casos el trabajo con vocabulario en qom o la participación de las familias en algunas conmemoraciones, como el 12 de octubre, entre otras actividades, pero no comportó ninguna modificación o reflexión más sistemática acerca de la modalidad educativa. Al respecto, señala Borton (2011, p. 90), la institución se atribuía la función de patronato respecto de la otredad, lo cual "permitiría [...] la recuperación de una identidad toba que era percibida como desdibujada al momento del contacto y [...] permitiría la reconducción de los niños tobas hacia una 'vida moral". En este punto, cabe mencionar que muchos agentes escolares parecían concebir que los/as niños/as y sus familias no eran tan "auténticamente tobas" pues habían vivido en asentamientos marginales en Buenos Aires y ahora vivían frente al edificio escolar. En la escuela aparecía la extendida representación de que, en Buenos Aires, los/as tobas están "fuera de lugar": el/la "toba auténtico/a" sería aquel/la que vivía en el pasado y el que actualmente vive en el Chaco, por lo que el/la que habita en Buenos Aires estaría, cuanto menos, en un territorio "ajeno".

En tanto el modelo de autenticidad refiere al "indígena rural", "hablante de la lengua indígena" y con las "creencias de sus ancestros", los/as niños/as del barrio parecen ser "menos indígenas", pues no viven sus vidas en el campo y la mayoría habla español como primera lengua:

Un día, al llegar a la escuela veo que una niña de 10 años está yendo y viniendo del patio en busca de algo con unos papeles. Al rato, vuelve con un hombre mayor del barrio, a quien había mandado a llamar porque en la escuela la vicedirectora le había pedido a ella que traduzca unas palabras del toba al castellano. Como apesadumbrada, me dice "yo le dije que no sabía"

Este es sólo un ejemplo de las interpelaciones que los/as niños/as reciben cotidianamente en la escuela. 
En muchos casos, las imágenes con las que son interpelados/as son recuperadas por los propios sujetos. Así, por ejemplo, la articulación hegemónica entre el ser católico, neuquino, argentino y despolitizadamente mapuche promovida por la congregación salesiana y el gobierno provincial neuquino, es en muchos casos asumida como propia por la población mapuche. Sin embargo, el testimonio de un hombre de alrededor de 40 años de edad, alumno interno durante su niñez, nos advierte sobre el carácter no mecánico de la recepción de tal interpelación -"Yo no sé si será como ellos cuentan esa historia de Ceferino ¡Cómo machacaban con eso de que "él era uno de ustedes'!"-; poniendo de manifiesto "la actividad silenciosa, transgresora, irónica o poética" de los "lectores" del mensaje en cuestión, "que conservan su actitud de reserva en privado y sin que lo sepan los 'maestros"' (de Certeau, 1998, p. 185). A su vez, los sujetos hacen "uso", se "valen de", el "orden imperante" en "un campo que los regula en un primer nivel [...], pero introducen una forma de sacar provecho de éste que obedece a otras reglas" (de Certeau, 1998, p. 36). De este modo, como la "inculturación" promovida por los salesianos implicó que se permita ocasionalmente a los/as niños/as internos asistir a la ceremonia del Gejipun ${ }^{11}$ en compañía de algún miembro del personal, esto solía y suele ser solicitado como medio para compartir unos días con sus familiares: "Así que fui a ver al cura y le dije "mire, eh, yo, eh, mi mamá quiere que nosotros estemos en el Gejipun [...] Y yo... en realidad yo no sé si iría para el Gejipun, yo, yo hacía todo eso para que me llevaran un rato a mi casa" (integrante organización mapuche). Registramos además, cómo algunos/as niños/as mapuche cuestionan abiertamente la propuesta sincrética salesiana, como por ejemplo un niño de 10 años que definió como criterio para ser mapuche "no ser religioso, por ejemplo de hablar de dios, todo eso", a lo cual contrapuso "hablar así entre los mapuche como saben, ${ }^{12}$ mapuzugun".

Tampoco los/as niños/as del barrio qom permanecen pasivos frente a las interpelaciones acerca de qué es lo indígena para la escuela; tal como hemos analizado en otro artículo (Hecht; García Palacios, 2010, p. 988),

11 Ceremonia comunitaria mapuche anual conducida por determinado linaje.

12 En las comunidades mapuche hemos registrado la utilización del verbo "saber" para indicar que se hace algo habitualmente. 
participan activamente en estas disputas de sentidos, como comentó un joven de 15 años:

Había unos chicos [de la escuela] que tenían que dar tobas [como lección escolar], y ahí, "el que tuviera alguna duda que levante la mano" dijeron y los otros empezaron a explicar, y entonces yo levanté la mano: “¿Por qué vivían?" [hace referencia a que sus compañeros hablan usando el tiempo pasado] y les empecé a explicar... "Porque siguen viviendo de la misma forma" y eran cosas de las que yo no estaba de acuerdo cuando hablaban los pibes.

En la escuela las interpelaciones sobre "su etnicidad" suelen ser percibidas como un señalamiento estigmatizante de "su otredad". A su vez, es por ser "portadores de etnicidad" que se les ha permitido ser incluidos en el establecimiento, aun siendo "no católicos": "a los únicos chicos que dejamos entrar que no sean católicos son los tobas" (vicedirector). Así, pese a que son llamados a participar de las actividades religiosas, aquí no parece construirse en el campo religioso un "nosotros" católico inclusivo, a diferencia del caso salesiano.

Por su parte, para las familias del barrio toba, y a pesar de las tensiones y diferencias que hay entre las distintas iglesias del Evangelio, el catolicismo se constituye en un divisor de aguas "entendido según los evangelio como condición amoral y errada" (Ceriani Cernadas, 2008, p. 266).

Así, mientras en la Patagonia la congregación salesiana continúa presentándose a sí misma como artífice de la vigencia de las tradiciones mapuche, en Buenos Aires la congregación aquí abordada no ha elaborado una propuesta que articule la pertenencia toba con la católica, sino que ese tipo de iniciativa ha caracterizado más bien al Evangelio, que, en contraposición del catolicismo, en Chaco y Buenos Aires se presenta a sí mismo para los/as evangelio como el vehículo por el cual se pudo dar continuidad a ciertos contenidos qom. Tal como ha señalado Wright (2008, p. 161), los/as tobas parecen recordar el contacto con la Iglesia Católica como una acción diseñada por el Estado para "civilizar y domesticar la cultura aborigen", lo cual condicionó la posterior visión del pentecostalismo como "liberador", pero, en muchos casos, al costo de la estigmatización de sus prácticas ancestrales, que sí son reivindicadas por quienes se oponen a los contenidos cristianos. 


\section{Palabras de cierre: Reflexiones sobre agencia y apropiación}

A lo largo del artículo intentamos reconstruir las complejas tramas identitarias que se entretejen en los encuentros entre estos/as diferentes niños/as y congregaciones religiosas, en dispares contextos. Del análisis comparativo desplegado surgen algunas reflexiones finales que aquí presentaremos. Hemos analizado las diversas facetas implicadas en los mensajes identitarios dirigidos a los/as niños/as indígenas -mapuche y qom- por la Iglesia Católica, específicamente por la congregación salesiana en Neuquén y la orden de religiosas en Buenos Aires, entre las que registramos coincidencias y diferencias.

Por un lado, ambos grupos religiosos han encauzado gran parte de sus esfuerzos evangelizadores hacia los/as niños/as, siguiendo la metodología que ya habían implementado en Italia con niños/as de sectores marginales. A su vez, en ambos casos se orientan a evangelizar a estos pueblos, a través de la educación de niños/as, considerados como más maleables que los/as adultos/as.

Por otro lado, una diferencia sobresaliente reside en que, mientras los salesianos, guiados por el sueño de Don Bosco, fueron en busca de las poblaciones indígenas de la Patagonia, y elaboraron específicamente una estrategia y contenidos para evangelizarlas, apelando a cierto sincretismo con la cultura y religiosidad mapuche, en el caso de la orden de la escuela de Buenos Aires, el colegio preexiste al barrio toba/qom, con cuya población se encontraron tardíamente y los admitieron en su institución en gran medida por caridad. Además, mientras que las escuelas salesianas les presentan una propuesta abiertamente sincrética, en la que sin embargo el componente mapuche queda subordinado a la adscripción al catolicismo, en el caso de la provincia de Buenos Aires, por presentarse abiertamente como evangelio, y por haber comenzado el contacto entre esta congregación y la comunidad qom en tiempos de "respeto a la diversidad", se define a los/as niños/as como "no católicos", a quienes se recibe en la escuela, "sin obligarlos" a realizar las prácticas religiosas, al menos no explícitamente.

Asimismo, nuestro análisis ha evidenciado el rol activo de las poblaciones indígenas en estos procesos de evangelización, al haber en ciertos casos generado nuevas iglesias -como el Evangelio-, en otros casos rechazado ciertas propuestas o bien habérselas apropiado entusiastamente, como evidenció también el trabajo comparativo entre los casos qom y mbya guaraní realizado por 
Enriz, García Palacios y Hecht (2017), mientras en muchas otras ocasiones el encuentro con estas propuestas católicas ha impulsado y fortalecido por oposición la recuperación de prácticas culturales propias (Szulc, 2018). Esta activa participación de los/as indígenas no es un fenómeno reciente. Como ha señalado de Certeau (1998, p. 38),

a menudo estos indios utilizaban las leyes, las prácticas o las representaciones que les eran impuestas por la fuerza o por la seducción con fines diversos a los buscados por los conquistadores; hacían algo diferente con ellas; las subvertían desde dentro; no al rechazarlas o al transformarlas (eso también acontecía), sino mediante cien maneras de emplearlas al servicio de reglas, costumbres o convicciones ajenas a la colonización de la que no podían huir.

En los casos que aquí hemos analizado, por un lado, las diferencias en las apropiaciones y resistencias se relacionan también con las particularidades de las propuestas. Así, como anticipamos, sólo en el caso de los salesianos en Neuquén encontramos el énfasis en la formación en oficios, lo que hace que en cierta medida, perdure la adhesión de parte de la población mapuche a sus escuelas. Por otro lado, el trabajo que aquí presentamos contribuye a comprender cómo participan los/as niños/as qom/toba y mapuche en estas tensas y dispares relaciones interétnicas.

A modo de cierre entonces, enfatizamos aquí aquellos intersticios generados o utilizados por los/as niños/as que ponen en cuestión el supuesto carácter monolítico y la linealidad de la recepción de las interpelaciones de las diversas iglesias. Al respecto, fuimos señalando con relación a ambas propuestas el modo en que ellos/as se apropian, reformulan o refuncionalizan las interpelaciones recibidas, a través de sus prácticas y representaciones. Al pensar en la apropiación de elementos culturales, la entendemos como un proceso que implica una selección, reelaboración y producción individual y colectiva de los recursos culturales, que posibilita la comprensión de una acción recíproca entre sujetos -individuales o colectivos- y diversas instituciones o grupos sociales (Rockwell, 1997). En este sentido, a lo largo de este artículo evidenciamos cómo estos niños, niñas y adolescentes, se han estado apropiando de "espacios, tiempos, palabras y saberes en las escuelas" (Rockwell, 2011, p. 33) en función de sus propios intereses, a través de prácticas de resistencia o de 
subversión que "no son acciones auto-condenadoras [...] que impidan su apropiación de los saberes escolares" (Rockwell, 2011, p. 49).

A su vez, la apropiación de un elemento cultural puede distinguirse de su dominio, ya que, siguiendo a Wertsch (1998), mientras que el segundo refiere a saber cómo utilizar esa herramienta cultural, la primera implica hacerla propia. Mediante la etnografía en ambos contextos, hemos podido registrar que muchas veces los/as niños/as "saben", "dominan", los contenidos que les ofrece la escuela -por ejemplo los que deben aprobar en las clases de catequesis-, pero no siempre se apropian de ellos. Esto revela que no necesariamente aquello que han logrado dominar es algo con lo que se identifican o estén dispuestos/as a hacerlo propio (Wertsch, 1998).

El trabajo aquí desplegado permite también una reflexión en torno al concepto de agencia infantil. Como hace tiempo venimos planteando, se trata de un interesante recurso que nos invita a poner atención a lo que niños/as dicen, sienten, piensan y hacen en los contextos en que habitan. Tal como sostienen también Nunes y Carvalho (2010), para reconocerlos/as como activos/as agentes sociales, la investigación antropológica no debería sólo dar lugar a sus "voces", sino a su vez tener en cuenta los efectos de sus prácticas en su entorno social. Así, en este trabajo comparativo hemos podido analizar cómo los/as niños/as introducen fisuras en las propuestas educativas católicas manipulando los plazos previstos institucionalmente para tomar la primera comunión, ensamblando interpelaciones que se les presentan como incompatibles, adhiriendo pero manteniendo a la vez una distancia, desoyendo intencionalmente aquellos mensajes que contradicen sus creencias, escapándose de los internados o haciendo uso del tiempo y logística institucional para actividades de ocio "mundanas".

Sin caer en interpretaciones románticas de la resistencia estudiantil según las cuales "los maestros son villanos y los estudiantes antihéroes" (McLaren, 1984, p. 231), consideramos de relevancia advertir cómo actúan desde lo que de Certeau (1979, p. 9) caracterizó como la "posición del débil", en tanto sacan "partido de las cartas ajenas en el instante decisivo, uniendo elementos heterogéneos cuya combinación asume la forma, no de un discurso previo, sino de un "golpe", de una acción".

Sin embargo, nos parece importante insistir una vez más en la necesidad de resistir la tentación de "sobreestimar el poder social de los niños y niñas" (Szulc, 2019, p. 61) y de aislarlos conceptual o metodológicamente de sus 
entornos socioculturales (Cohn, 2005; García Palacios; Horn; Castorina, 2015; Pires, 2007; Szulc, 2004, 2015), "pues los niños y niñas comparten sus mundos con diferentes adultos, aunque no en condiciones de igualdad" (Szulc, 2019, p. 61). El análisis comparativo de las interpelaciones identitarias propuestas por diferentes grupos católicos a niños/as mapuche y qom puede así también nutrir debates conceptuales relevantes para la antropología de las infancias, al evidenciar la importancia de contextualizar la "agencia infantil" y sus modos de apropiación de lo que se les transmite, situándolos/as sociohistórica y culturalmente, en el marco de relaciones de poder intergeneracionales, interétnicas, de clase y de género.

\section{Referencias}

ALVARES, M. M. Kitoko Maxakali: a criança indígena e os processos de formação, aprendizagem e escolarização. Revista AntHropologicas, Recife, v. 15, n. 1, p. 49-78, 2004.

ARIÈS, P. El niño y la vida familiar en el Antiguo Régimen. Madrid: Taurus, 1987.

ARTIEDA, T.; HECHT, A. C. El tratamiento de lo indígena en los estudios de Historia de la Educación en la Argentina: diálogos con la Antropología. In: JORNADAS ARGENTINAS DE HISTORIA DE LA EDUCACIÓN, 17., 2012, Tucumán. Anales [...]. Tucumán: Universidad Nacional de Tucumán, 2012. p. 1-12.

ARTIEDA, T.; ROSSO, L. Propuestas educativas para aborígenes del norte argentino en las fases del proceso de proletarización. 1884-1922. In: ASCOLANI, A. (comp.). El sistema educativo en Argentina: nuevas perspectivas históricas. Rosario: Laborde Editor, 2005. p. 70-87.

ASAD, T. The construction of religion as an anthropological category. In: ASAD, T. Genealogies of religion. Baltimore: Johns Hopkins University Press, 1993. p. 27-54.

ASTUTI, R. Les gens ressemblent-ils aux poulets? Penser la frontière homme-animal à Madagascar. Terrain, [s. l.], n. 34, p. 89-106, 2000.

BORTON, L. Representaciones docentes sobre los niños tobas y sobre el silencio en una escuela en situación de interculturalidad. In: NOVARO, G. (coord.). La interculturalidad en debate: experiencias formativas y procesos de identificación en niños indígenas y migrantes. Buenos Aires: Biblos, 2011. p. 85-103.

BOURDIEU, P. Qué significa hablar. Madrid: Akal, 1985. 
BOURDIEU, P. Génesis y estructura del campo religioso. Relaciones, [s. l.], v. 27, n. 108, p. 29-83, 2006.

BRAUNSTEIN, J.; MILLER, E. Ethnohistorical introduction. In: MILLER, E. (ed.). Peoples of the Gran Chaco: Native Peoples of the Americas. West Port: Bergin \& Garvey, 1999. p. 1-22.

BRIONES, C. Weaving "the Mapuche People": the cultural politics of organizations with Indigenous philosophy and leadership. 1999. Dissertation (PhD) - University of Texas at Austin, Austin, 1999.

BRIONES, C.; LANATA, J. L. Living on the edge (still). In: BRIONES, C.; LANATA, J. L. (ed.). Contemporary perspectives on the native peoples of Pampa, Patagonia and Tierra del Fuego: living on the edge. Connecticut: Bergin and Garvey's Co, 2002. p. 1-16.

CAMPIGOTTO, M. Mondes d'enfants. Ethnographie des "premières communions" à la paroisse Natività di Maria Vergine. AnthropoChildren, [s. l.], n. 2, p. 1-21, 2012. Disponible en: https://popups.uliege.be/2034-8517/index.php?id=1478. Acceso: 28 mar. 2020.

CAROZZI, M. J.; CERIANI CERNADAS, C. (coord.). Ciencias sociales y religión en América Latina: perspectivas en debate. Buenos Aires: Biblos, 2007.

CERIANI CERNADAS, C. Nuestros hermanos lamanitas: indios y fronteras de la imaginación mormona. Buenos Aires: Biblos, 2008.

CERIANI CERNADAS, C.; CITRO, S. El movimiento del evangelio entre los tobas del Chaco argentino. Una revisión histórica y etnográfica. In: GUERRERO JIMÉNEZ, B. (ed.). De indio a hermano: pentecostalismo indígena en América Latina. Santiago de Chile: Campvs, 2005. p. 111-170.

CODONHO, C. G. Aprendendo entre pares: a transmissão horizontal de saberes entre as crianças indígenas Galibi-Marwono (Amapá, Brasil). 2007. Dissertação (Mestrado em Antropologia Social) - Centro de Filosofia e Ciências Humanas, Universidade Federal de Santa Catarina, Florianópolis, 2007.

COHN, C. A experiência da infância e o aprendizado entre os Xikrin. In: LOPES DA SILVA, A.; MACEDO, A. V. L. S.; NUNES, A. (org.). Crianças indígenas: ensaios antropológicos. São Paulo: Global, 2002. p. 117-149.

COHN, C. Antropologia da criança. Rio de Janeiro: Zahar, 2005.

CSORDAS, T. J. Growing up charismatic: morality and spirituality among children in a religious community. Ethos, [s. l.], v. 37, n. 4, p. 414-440, 2009. 
DE CERTEAU, M. Pratiques quotidiennes. In: POUJOL, G.; LABOURIE, R. (dir.). Les cultures populaires. Toulouse: Privat, 1979. p. 23-30. ["Prácticas cotidianas", traducción de Laura López, revisión de Gilberto Jiménez Montiel. Mimeografiado.]

DE CERTEAU, M. La invención de lo cotidiano: I. Artes de hacer. México: Luce Giard: Universidad Iberoamericana, 1998.

DELRIO, W. Confinamiento, deportación y bautismos: misiones salesianas y grupos originarios en la costa del Río Negro (1883-1890). Cuadernos de Antropología Social, Buenos Aires, n. 13, p. 131-155, 2001.

DULLO, E. Comparação: implícita, explícita e valor. Mana, Rio de Janeiro, v. 25, n. 1, p. 220-235, 2019.

ENRIZ, N. Juegos, saberes y experiencias infantiles mbyá-guaraní en Misiones. München: Lincom, 2011.

ENRIZ, N.; GARCÍA PALACIOS, M.; HECHT, A. C. Llevar La palabra. Un análisis de la relación entre las iglesias y la escolarización de niños indígenas tobas/qom y mbya-guaraní de Argentina. Universitas Humanística, Bogotá, n. 83, p. 187-212, 2017.

UNA ESCUELA que mantiene viva la cultura mapuche. In: OBRA de Don Bosco. [S. l.: s. n.], 2007. Disponible en: http://www.obradedonbosco.org.ar/notas/nota. asp? IdNota=137\&IdSeccion=58. Acceso: 2 jul. 2007.

EVANS-PRITCHARD, E. E. Las teorías de la religión primitiva. Madrid: Siglo XXI, 1991.

FALCÃO, R. C. Playing at possession. How do children come to grips with spirit possession. Childhood's Today, [s. l.], v. 8, n. 1, p. 1-15, 2014.

FOUCAULT, M. Vigilary castigar: nacimiento de la prisión. Buenos Aires: Siglo XXI, 1989.

GARCÍA PALACIOS, M. La catequesis como experiencia formativa: las construcciones de los niños acerca de las formas simbólicas de la religión católica. 2006. Tesis (Licenciatura en Ciencias Antropológicas) - Universidad de Buenos Aires, Buenos Aires, 2006.

GARCÍA PALACIOS, M. Religión y etnicidad en las experiencias formativas de los niños y niñas de un barrio toba de Buenos Aires. 2012. Tesis (Doctorado en Antropología Social) - Universidad de Buenos Aires, Buenos Aires, 2012.

GARCÍA PALACIOS, M. Going to the churches of the Evangelio: children's perspectives on religion in an indigenous urban setting in Buenos Aires. Childhood's Today, [s. l.], v. 8, n. 1, p. 1-25, 2014. 
GARCÍA PALACIOS, M. La escuela (católica) cotidiana. Una aproximación etnográfica a las experiencias formativas escolares de los niños y niñas de un barrio toba/ qom de Buenos Aires. Cuadernos del Instituto Nacional de Antropología y Pensamiento Latinoamericano, [s. l.], v. 27, n. 1, p. 61-79, 2018.

GARCÍA PALACIOS, M. La educación religiosa en disputa: niños, niñas y jóvenes toba/qom entre las iglesias del Evangelio y la Escuela Católica. Education Comparée, [s. l.], v. 21, n. 1, p. 151-171, 2019.

GARCÍA PALACIOS, M. et al. Religión y niñez. Una revisión de las investigaciones en antropología. Revista Sociedad y Religión, [s. l.], v. 26, n. 45, p. 170-183, 2016.

GARCÍA PALACIOS, M. et al. Educación, niñez y religión. Una revisión en busca de coordenadas para su estudio. Religião \& Sociedade, Rio de Janeiro, v. 38, n. 1, p. 181-195, 2018.

GARCÍA PALACIOS, M.; HORN, A.; CASTORINA, J. A. Prácticas sociales, cultura e ideas infantiles. Una convergencia entre la antropología y la psicología genética crítica. Estudios de Psicología, [s. l.], v. 36, n. 2, p. 211-239, 2015.

GEERTZ, C. La religión como sistema cultural. In: GEERTZ, C. La interpretación de las culturas. Barcelona: Gedisa, 1992. p. 87-117.

GÉLIS, J. La individualización del niño. In: ARIÈS, P.; DUBY, G. (ed.). Historia de la vida privada: del Renacimiento a la Ilustración: vol. III. Madrid: Taurus, 1990. p. 311-329.

GIORDANO, M. Itinerario de imágenes del indígena chaqueño: del Territorio Indio del Norte al Territorio Nacional y Provincia del Chaco. Anuario de Estudios Americanos, [s. l.], v. 61, n. 2, p. 517-550, 2004.

GOFFMAN, E. Internados: ensayos sobre la situación social de los enfermos mentales. Buenos Aires: Amorrortu, 1998.

GORDILLO, G. En el Gran Chaco: antropología e historias. Buenos Aires: Prometeo, 2006.

GOTTLIEB, A. Do infants have religión?. American Anthropologist, [s. l.], v. 100, n. 1, p. 122-135, 1998.

GOTTLIEB, A. The afterlife is where we come from: the culture of infancy in West Africa. Chicago: The University of Chicago Press, 2004.

GUERRERO JIMENEZ, B. (comp.). De indio a hermano: pentecostalismo indígena en América Latina. Santiago de Chile: Campvs, 2005. 
HALL, K. There's a time to act English and a Time to Act Indian: the politics of identity among British-Sikh teenagers. In: STEPHENS, S. (ed.). Children and the politics of culture. Princeton: Princeton University Press, 1995. p. 243-264.

HALL, K. "You can't be religious and be westernized". In: HALL, K. Lives in translation: Sikh youth as British citizens. Philadelphia: University of Pennsylvania Press, 2002. p. 148-169.

HECHT, A. C. "Todavía no se hallaron hablar en idioma”: procesos de socialización lingüística de los niños en el barrio toba de Derqui, Argentina. München: LINCOM EUROPA, 2010.

HECHT, A. C.; GARCÍA PALACIOS, M. Categorías étnicas en el entramado social. Un estudio con niños y niñas de un barrio indígena. Revista Latinoamericana en Ciencias Sociales, Niñez y Juventud, [s. l.], v. 8, n. 2, p. 981-993, 2010.

LEAVY, P.; SZULC, A.; ANZELIN, I. Niñez indígena y desnutrición: análisis antropológico y comparativo de programas alimentarios en Argentina y Colombia. Revista Cuadernos de Antropología Social, [s. l.], n. 48, p. 39-54, 2018.

LEITÃO SOUZA, A. “Tia, o que é religião?”: religião, corpo e negociação entre crianças na cidade mais evangélica do país. Debates do NER, Porto Alegre, v. 19, n. 33, p. 101-136, 2018.

LOIS, C. La invención del desierto chaqueño: una aproximación a las formas de apropiación simbólica de los territorios del Chaco en los tiempos de formación y consolidación del Estado Nación Argentino. Scripta Nova: Revista Electrónica de Geografía y Ciencias Sociales, [s. l.], año 3, n. 38, p. 1-17, 1999.

LOPES DA SILVA, A.; MACEDO, A. V. L. S.; NUNES, A. (org.). Crianças indígenas: ensaios antropológicos. São Paulo: Global, 2002.

MAHMOOD, S. Teoria feminista, agência e sujeito liberatório: algumas reflexões sobre o revivalismo islâmico no Egito. Etnográfica, Lisboa, v. 23, n. 1, p. 121-158, 2019.

MALINOWSKI, B. Magia, ciencia y religión. Barcelona: Planeta De Agostini, 1994.

MALLIMACI, F. Diversidad católica en una sociedad globalizada y excluyente. Una mirada al fin del milenio desde Argentina. Sociedady Religión, [s. l.], n. 14/15, p. 71-94, 1996.

MARTÍNEZ SARASOLA, C. Nuestros paisanos los indios. Buenos Aires: Emecé, 1992.

McLAREN, P. La vida en las escuelas. México: Siglo XXI, 1984.

MONTERO, P. (org.). Deus na aldeia: missionários, índios e mediação cultural. São Paulo: Globo, 2006. 
NICOLETTI, M. A. Indígenas y misioneros en la Patagonia. Buenos Aires: Continente, 2008.

NUNES, A.; CARVALHO, M. R. Questões metodológicas e epistemológicas suscitadas pela Antropologia da Infância. Revista BIB/ANPOCS, São Paulo, n. 68, p. 77-97, 2010.

OLIVEIRA, M. S. de. Nhanhembo'e: infancia, educaçao e religião entre os Guarani de M’Biguaçu. Cadernos de Campo, São Paulo, n. 13, p. 75-89, 2005.

ORSI, R. Between Heaven and Earth: the religious worlds people make and the scholars who study them. Princeton: Princeton University Press, 2005.

PADAWER, A. et al. Alfabetización y evangelización: Intervenciones educativas hacia los qom en el marco de congregaciones religiosas. In: NOVARO, G. et al. (coord.). Niñez, regulaciones estatales y procesos de identificación: experiencias formativas en contextos de diversidad y desigualdad. Buenos Aires: Biblos, 2017. p. 187-216.

PALMER, S.; HARDMAN, C. Children in new religions. New Jersey: Rutgers University Press, 1999.

PIOVANI, J. I.; KRAWCZYK, N. Los Estudios Comparativos: algunas notas históricas, epistemológicas y metodológicas. Educação \& Realidade, Porto Alegre, v. 42, n. 3, p. 821-840, 2017.

PIRES, F. Quem tem medo de mal-assombro?: religião e infância no semi-árido nordestino. 2007. Tese (Doutorado em Antropologia Social) - Museu Nacional, Universidade Federal do Rio de Janeiro, Rio de Janeiro, 2007.

PRIORE, M. del. O papel branco, a infância e os jesuítas na colônia. In: PRIORE, M. del (org.). História das crianças no Brasil. São Paulo: Contexto, 1991. p. 10-27.

RADOVICH, J. C. El pentecostalismo entre los mapuche del Neuquén. Relaciones de la Sociedad Argentina de Antropología, Buenos Aires, v. 15, n.s., p. 121-132, 1983.

RIDGELY BALES, S. When I was a child: children's interpretations of first communion. Chapel Hill: The University of North Carolina Press, 2005.

ROCKWELL, E. La dinámica cultural en la escuela. In: ÁLVAREZ, A. (ed.). Hacia un currículum cultural: un enfoque vygotskiano. Madrid: Fundación Infancia y Aprendizaje, 1997. p. 21-28.

ROCKWELL, E. Los niños en los intersticios de la cotidianeidad escolar. ¿Resistencia, apropiación o subversión?. In: BATALLÁN, G.; NEUFELD, M. R. (coord.). Discusiones sobre infancia y adolescencia: niños y jóvenes dentro y fuera de la escuela. Buenos Aires: Biblos, 2011. p. 27-51. 
ROGOFF, B. Los tres planos de la actividad sociocultural: apropiación participativa, participación guiada y aprendizaje. In: WERTSCH, J.; DEL RÍO, E. (ed.). La mente sociocultural: aproximaciones teóricas y aplicadas. Madrid: Fundación Infancia y Aprendizaje, 1997. p. 111-128.

SANTILLÁN, L. Prácticas cotidianas e intersecciones entre la Iglesia Católica y grupos familiares en asentamientos populares del Gran Buenos Aires. Cadernos de Campo, São Paulo, n. 17, p. 111-132, 2009.

SEGATO, R. La nación y sus otros: raza, etnicidad y diversidad religiosa en tiempos de políticas de identidad. Buenos Aires: Prometeo, 2007.

SZULC, A. Niños: los otros "otros". In: REUNIÓN DE ANTROPOLOGÍA DEL MERCOSUR, 3., 1999, Posadas. Anales electrónicos [...]. Posadas: Universidad Nacional de Misiones, 1999.

SZULC, A. La antropología frente a los niños: de la omisión a las culturas infantiles. In: CONGRESO ARGENTINO DE ANTROPOLOGÍA SOCIAL, 7., 2004, Córdoba. Anales electrónicos [...]. Córdoba: Universidad Nacional de Córdoba, 2004.

SZULC, A. "Mi peñi Ceferino". Disputas identitarias en clave religiosa en torno a niños mapuche del Neuquén. Revista TEFROS, [s. l.], v. 9, p. 1-27, 2011 a.

SZULC, A. "Esas no son cosas de chicos". Disputas en torno a la niñez mapuche en el Neuquén, Argentina”. In: POVEDA, D.; FRANZÉ, A.; JOCILES, M. I. (coord.). Etnografías de la infancia: discursos, prácticas y campos de acción. Madrid: Editorial La Catarata, 2011b. p. 77-107.

SZULC, A. La niñez mapuche: sentidos de pertenencia en tensión. Buenos Aires: Biblos, 2015.

SZULC, A. Niñez mapuche, revitalización ritual y procesos de etnogénesis. Avá: Revista de Antropología, Posadas, n. 32, p. 81-107, 2018.

SZULC, A. Más allá de la agencia y las culturas infantiles. Reflexiones a partir de una investigación etnográfica con niños y niñas mapuche. Runa: Archivo para las Ciencias del Hombre, Buenos Aires, v. 40, n. 1, p. 53-64, 2019.

TASSINARI, A. Concepções indígenas de infância no Brasil. Tellus, Campo Grande, ano 7, n. 13, p. 11-25, 2007.

TEOBALDO, M. Sobre maestros y escuelas: una mirada a la educación desde la historia. Neuquén 1884-1957. Rosario: Arcasur, 2000. 
TOREN, C. Making sense of hierarchy: cognition as social process in Fiji. London: London School of Economics, 1990.

TOREN, C. Becoming a Christian in Fiji: an ethnographic study of ontogeny. Journal of the Royal Anthropological Institute, [s. l.], v. 10, p. 709-727, 2003.

VARELA, J.; ÁLVAREZ URÍA, F. Arqueología de la escuela. Madrid: La Piqueta, 1991.

VILAÇA, A.; WRIGHT, R. (ed.). Native Christians: modes and effects of Christianity among indigenous peoples of the Americas. Farnham: Ashgate Publishing, 2009.

WERTSCH, J. La mente en acción. Buenos Aires: Aique, 1998.

WILLIS, P.; TRONDMAN, M. Manifesto for ethnography. Ethnography, [s. l.], v. 1, n. 1, p. 5-16, 2000.

WRIGHT, P. Ser en el sueño: crónicas de historia y vida toba. Buenos Aires: Biblos, 2008.

ZAPATA, L. La mano que acaricia la pobreza: etnografía del voluntariado católico. Buenos Aires: Antropofagia, 2005.

Recebido: 31/03/2020 Aceito: 04/03/2021 | Received:3/31/2020 Accepted:3/4/2021 